\title{
Effect of Some Food Colorants (Synthetic and Natural products) of Young Albino Rats
}

\author{
I- Liver and Kidney Functions
}

\author{
Eman G. E. Helal ${ }^{(1)}$ Samir A.M.Zaahkouk ${ }^{(2)}$ \\ and Hamdy A. Mekkawy ${ }^{(3)}$. \\ ${ }^{(1)}$ Zoology Department, Faculty of Science for Girls, Al - Azhar University \\ , Nasr City, Cairo. \\ ${ }^{(2)}$ Zoology Department, Faculty of Science, Al - Azhar University, Nasr City, Cairo. \\ ${ }^{(3)}$ The National Center For Social and Criminological Research, \\ Zamalek P. O., P. C. 11561, Cairo, Egypt
}

\begin{abstract}
Food colorants are used all over the world in great amount. However, their use in food is still controversial. It causes and will cause severe tension to the consumers as the sensitivity of people increases to general health.

This work was carried out to study and compare between the possible toxic effect of some natural (tumeric, carmine and chlorophyll) and synthetic (fast green, annatto and sunset-yellow), food colorants on liver and kidney function of young male albino rats. Such effect might explain hyperactivity of children that was claimed associated with consumption of food colorants.

The study revealed that administration of both natural and synthetic food colorants (permitted dose) significantly increases serum AST and serum urea. All colorants with the exception of sun-set yellow significantly increase serum total bilirubin. While, chlorophyll, fast-green and sun-set yellow were significantly increase serum ALT. Some of the colorants used have a retard destructive effect on some vital organ functions, which extends even after the recovery period. Therefore, large quantities and /or long periods of colorants administration should not be used as additive in man's diet or as a drink. Hence, these colorants should restrictly be used in nutritional therapy. And more caring must be done prevent our children to eat or drink these colorants with much amounts or for long period.
\end{abstract}

\section{Introduction}

Material of natural origin have been used to provide colour in foods, drugs and cosmetics for the thousands of years. Ash from fires, mineral compounds and plants were probably among the first materials used for cosmetic purposes ( Gount et al. , 1972) Later, it was discovered that certain materials, mostly plant derived, could be used to enhance the appearance of foods and thus tumeric, paprika and saffron were used for more than just their flavouring properties. In the nineteenth century, synthetic organic dyes were developed to provide a more economical and extensive array of 
colorants ( Salah, 1994 ). By the early 1995, natural and synthetic colour additives were used extensively to colour foods, drugs and cosmetics (Hallagan et al., 1995).

Colour is an important characteristic and selection criterion for food choice.

Recent studies have highlighted this importance and have shown how selection may change among certain populations, and over time (Clydesdale, 1993). Colour is important for cosmetic purposes among many populations, and also for safety purposes such as the identification of pharmaceuticals. Colour additives exempt from certification are used for a wide variety of purposes in foods, drugs and cosmetics (Van-Bever, 1989).

Although all colour additives are alike in terms of the FDA's regulatory definition, they are regulated in two classes; the certified (synthetic) colour additives, and the colour additives exempt from certified (natural). Colorants play a significant role in enhancing the aesthetic appeal of food. Foods that are aesthetically pleasing are more likely to be consumed and to contribute to a varied diet (Newsome, 1986 and Hallagan , 1995).

Although the importance of food colorants, a wave of awareness and concern about the many adverse effects of synthetic food colorants on human health are ever growing ( Van Bever et al ,1989). In Egypt, there has been a sharp increase in the use of synthetic food colorants in the past few years and additionally there is an uncontrolled use of synthetic colour particularly in food mostly consumed by children (Salah, 1994). More attention must be focused on the physiological and pathological effects of colour additives (Ganong, 1991). The present investigation is planed to compare and illustrate the effects of three natural and three synthetic colour additives on hepatic and renal functions of small albino rats.

\section{Material and Methods}

Experimental animals:

Male albino rats (Rattus norvigicus) were used in the present study. Their body weight ranged between $70-90$ grams and their ages ranged from $1-1$ $1 / 2$ months. Animals were placed 10 rats in each cage, and maintained on a standard pellet diet and water. The diet composed of about $20 \%$ protein, $5 \%$ fibers, $3.5 \%$ fats and $6.5 \%$ ash and supplied with vitamins and mineral mixture. Food and water were allowed ad libitum. The animals were divided into 7 main groups

(10 rats/ each).

\section{Control group:}

Ten male rats served as a control group.

Annato treated group:

Individuals of this group received a dose of Annato $(1.25 \mathrm{mg} / \mathrm{kg}$. b. wt daily).

\section{Carmine treated group:}

Animals of this group received a dose of carmine $(1.25 \mathrm{mg} / \mathrm{kg}$. b. wt daily).

\section{Chlorophyll treated group:}

This group orally administered chlorophyll $(12.5 \mathrm{mg} / \mathrm{kg}$. b. wt daily).

\section{Fast green F.C.F. group:}

This group administered fast green F.C.F.( $12.5 \mathrm{mg} / \mathrm{kg}$. b. wt daily).

\section{Tumeric group:}

Rats in this group administered tumeric $(2.5 \mathrm{mg} / \mathrm{kg}$. b. wt daily).

\section{Sunset yellow F.C.F. group:}

This group orally administered sunset yellow ( $5 \mathrm{mg} / \mathrm{kg}$. b. wt daily).

After 30 days of treatment, 5 animals of each group were decapitated. While the other half of each group was kept for two weeks, without any additional treatment, to follow up if any sign of recovery. 


\section{Effect of Some Food Colorants}

All animals were weighed at the beginning of the experiment and before decapitation . After decapitation, animals were dissected, liver and kidneys were excised and weight. The percentage of hepatosomatic index and kidney /b. wt. were calculated. Pieces of liver and kidney were weighed and put in an appropriate amount of $30 \%$ potassium hydroxide for total protein determination.

\section{Blood sampling:}

Blood was taken in clean, sterile centrifuge tubes and allowed to stand for 2 hour at $4^{\circ} \mathrm{C}$, then centrifuged at 3000 r.p.m. for $20 \mathrm{~min}$. The serum separated was stored in deep freezer at $20{ }^{\circ} \mathrm{C}$ till used for analysis to the following parameters:

Serum aspartate -amino transferase (AST) and alanine-amino transferase (ALT) were determined according to the method of Reitman and frankel (1975).

Serum bilirubin was measured by Straumfjord and Jane (1973) method.

Kinetic determination of serum creatinine activity was measured according to Schrimeister (1964).

Serum urea was determined colourimetrically using the method of Patton and Crouch (1979).

Serum total protein was estimated using the Biuret method as described by Doumas (1975).

Albumin was determined according to Webester (1977).

Phosphorus was determined according to the method of Fiske and Subbarow (1925).

Serum calcium $\left(\mathrm{Ca}^{++}\right)$concentration was estimated according to the method adopted by Ray Sarkar and Chauhan (1967).

Statistical analysis:For comparison the different experimental animal group, the student-t-test was used. Significant differences between the means of control and treated groups were considered only when $\mathrm{p}$ was $<0.05$ (Sokal and Rohlf, 1981).

\section{Results:}

It was noticed that after administration of colorants, rats became more active, nervous and aggressive. Also, irritation was noticed after administration of sunset yellow.

It is clear that colours treatment resulted in an initial reduction of the mean body weight gain of all treated groups. This reduction was evident in those groups treated with annatto, tumeric and sun-set yellow $(\mathrm{P}<0.01)$ for the two periods of treatment. Yet, it was less pronouncing $(\mathrm{P}<0.05)$ for groups treated with chlorophyll, fastgreen and carmine till the end of the experiment (Table 1).

Hepato-somatic index and kidney/body weight of all colours treated groups showed no significant difference throughout the experimental period (Table 1).

As regard to the effect of oral administration of colorants on liver function, the data obtained revealed a marked increase $(\mathrm{P}<0.05)$ in the serum AST level of all treated groups after 30 days of treatment and it lasted to the end of the experiment (after 15 days of recovery) in these groups treated with annatto and sunset yellow only. However, after 15 days of recovery the increase was in normal range in the other groups (Table 2). After one month of treatment serum ALT activity showed a significant increase $(\mathrm{P}<0.05)$ in groups treated with chlorophyll, fastgreen and sun-set yellow. On the other hand, rats treated with carmine, annatto and tummeric showed insignificant change after the same period of treatment. However, after 15 days of recovery, all groups showed insignificant change as compared with 
the control group (Table 2). All groups treated with colorants with the exception of sun set yellow revealed a significant increase $(P<0.05)$ of serrum total bilirubin after one month of treatment. But after the recovery period, all treated rats showed insignificant change.

All treated groups consumed insignificant change in serum direct billirubin after both treated and recovery period (Table 1). While, serum indirect billirubin showed a significant increase $(\mathrm{P}<0.05)$ after treated period in case of rats treated with carmine, sunset yellow and chlorophyll. Yet, it was statistically insignificant with all treated groups after the recovery period (Table 1).

Data in Table (3) revealed that oral administration of tumeric and sunset yellow induced insignificant change in serum creatinine after 30 days of treatment and after 15 days posttreatment while administration of annatto induced a $(\mathrm{P}<0.01)$ after 30 days of treatment and a significant increase $(\mathrm{P}>0.05)$ at 15 days posttreatment. Similarly, groups treated with carmine, chlorophyll and fastgreen showed a significant increase $(\mathrm{P}<$ $0.05)$ after the treated period and still lasting till the end of the experiment with the group of fast green only.

Table (3) revealed that a highly significant increase of serum urea $(\mathrm{P}<$ 0.01) was recorded after 30 days of treatment for all colorants used, also the rest period showed a significant increase $(\mathrm{P}<0.05)$ in all treated groups.

Non-significant changes were observed in serum uric acid of all treated groups after 30 days of treatment and 15 days post-treatment.

Total serum protein was significantly decreased $(\mathrm{P}<0.05)$ in case of carmine and sunset yellow treated groups only after 30 days of treatment. While, other groups showed insignificant changes. After 15 days post treatment insignificant changes of total serum protein was recorded in all the colorants used (Table 4). Furthermore, all colorants treatment of the rats showed insignificant changes in serum albumin throughout the experimental period.

On the other hand, the serum globulin also decreased $(\mathrm{P}<0.05)$ in case of chlorophyll and fast green treatment after the treated period. This decrease was more pronouncing $(\mathrm{P}<$ 0.01 ) in case of carmine and sunset yellow treatment. But, serum globolin of annatta and tumeric groups was not affected. However, in significant changes of serum globulin after the recovery period was recorded for all treated groups (Table 4). Furthermore, the present data showed insignificant changes of total protein of liver, kidney, heart, muscle and brain during all the period of the experiment for all colorants used.

Concerning serum calcium and phosphorus contents, the data showed no significant difference of all treated groups throughout the experimental period (Table 6).

Discussion:

In the present study, rats showed many signs of behavioral variations like hyperactivity, nervous motion and became aggressive to each other after administration of all colours used. But, specially after sunset yellow administration, skin irritation was noticed. In agreement with these results, Juhlin (1981), Twaroj (1983), Hong (1989) stated that food additives are a common cause of chronic urticaria and angioedema in patients. Food additives also caused positive skin and/or intestinal reaction (Van-Bever, 1989) irritability, restlessness and sleep disturbance (Rowe, 1988). 


\section{Effect of Some Food Colorants}

However, the body weight generally decreased (in all colours used). A similar finding was also recorded in rats (Brozelleca et al., 1989 and Abou ElZahab et al., 1997) and in boys (Booth, 1993). Also, Osman et al. (1995) stated that synthetic food colorants cause a significant increase in body weight gain until the fourth month followed by a significant decrease in male and female mice.

The present study showed insignificant changes in hepato-somatic index and kidney/body weight. In agreement with the present results, Gaunt et al. (1969) recorded that carmoisine had no effect on organ weight in pig. On the other hand, Osman et al. (1995) reported that synthetic food colorants increased organ/body weight in mice. Also, Gaunt et al. (1967) found an elevation in the relative kidney weight in female rats after administration of curmoisine for 90 days.

The significant increase in the activities of serum AST and ALT in rats treated with chlorophyll, fast-green and sun-set yellow may be due to the haptic potency of these colours resulting in destructive changes in the hepatic cells. The colours were administered orally and, hence, they reach the liver first through the portal vein. The effect of the colorants on the liver is in accordance with Abdel-Rahim et al. (1987a, b and 1989), Ibrahim et al. (1988), Gaunt et al. (1972) and Abou El-Zahab et al. (1997) who recorded a pronounced increase of serum and liver transaminases activity in rats ingested synthetic colorants. AST is considered to be more specific for heart function tests, (Ganong, 1991), its activity is increased in plasma of all groups after the treated period and disapeared after the recovery period in all groups except these treated with annatto and sunset yellow. So, we suppose that sun-set yellow has a retard damage effect on heart function. Also, the increase of serum total bilirubin in all colorants used, with the exception of sun-set yellow, may be due to defect in liver function produced from hepatacellular damage. So, it seems that both natural and synthetic colorants have a destructive effect on both liver and heart functions. But more investigation must be done by using more specific tests to illustrate the accurate level of damage ( Ibrahim et al., 1988).

It's clear from the present data that all colorants used had no effect on serum uric acid. While all of them highly increased serum urea. Colorants used also increased serum creatinin except tumeric and sunset yellow. We believe that the significant elevation in urea and creatinine levels is closely related to the impairment of renal function. These results are in agreement with Varley (1976) who decided that the blood urea can be increased in all forms of kidney diseases such as hydronephrosis congenital cystic kidney, renal tuberculosis, condition in which deposition of calcium occurs as hypervitaminosis D. He also stated that plasma creatinine increases in renal diseases gave prognostic significance than those of other nitrogenous substances. On the other hand, Mackenzie et al. (1992) stated that caramel color intravenous (IV) reduced blood urea nitrogen in rats.

From the experimental point of view, serum total protein was noticed to decrease under the effect of carmine and sun-set yellow. This was accompained with a marked depletion of serum globulin. Also, chlorophyll and fast green showed a significant decrease in serum globulin. These results find good support of the studies carried out by Sharma (1989) and Mackenzie et al. 
(1992) who illustrated a marked decrease of serum protein in rats after treatment with metanile yellow or caramel colour. The inhibition of protein synthesis is reversible and not specific. The present results would confirm these findings since serum total protein was diminished after treatment with both carmine and sunset yellow. However, such depletion was apparently time dependent since it disappears after the recovery period. This decrease may be due to the reduction of serum globulin level which markedly declined at the same time. It supports thes previously mentioned disturbances of the liver functions. The decrease may be an indication of a delayed depressing effect of the colorants used on immunoglobulin production, the defense mechanism which aims to protect the body from the toxic effects. This was in contrast with the findings of Abdel Rahim et al. (1989) and Robet et al. (1993) who stated that the globulin fraction in the serum of rats recorded an increase induced by colors after a period of 60 days.

The present study showed insignificant changes in serum calcium and phosphorus contents for all colorants used. The results obtained in this work revealed that the present limited dose of carmine, annatto, tumeric, sun-set yellow, chlorophyll and fast-green should not be used as additives to the diets or as a drink for human. Also they should restrictly be used in nutritional therapy. Although, the tested colorants, insignificantly changed some biochemical parameters, but inspite of the present doses had a dangerous effect on liver and kidney functions. Also, it's clear that the recovery period (the prevention of their usage) could ameliorate their damage effect. The data obtained suggested that the proper concentration of tested colorants should be firstly examined before use.

\section{REFERENCES}

Abdel-Rahim, E.A.; Ahmed, F.A.; ElDesoky, G.E. and Ramadan, M.E. (1987a): biochemical role of some natural and synthetic food colourants on liver function of rats. Minia. J. Agric. Res. Dev., 9(3):11-17.

Abdel-Rahim, E.A.; El-Desoky, G.E.; Shousha, M.M. and Mahrous, T.S.A (1987b): Study of certain biochemcial changes under the effect of some synthetic and natural colorants in rats. Proceedings of the 2nd national Conf. of Physiological Sciences, Cairo, 30-31 Dec., p. 82.

Abdel-Rahim, G.A. (1989): Effect of some natural and synthetic food colorants on protein nucleic acids and nucleases in albino rats organs. Minia. J. Agric. Res. and Dev., 10(4):15-18.

Abou El-Zahab, H.S.H.; El-Khyat, Z.A.; Awadallah, R. and Mahdy, K.A. (1997): Physiological effects of some synthetic food coloring additives on rats. Boll. Chim. Farm., 136(10):615627.

Booth, J. (1993): food intolerence in a child with urticaria. J. Human Nutrition and Diebetics, 6(4):377-380.

Brozelleca, J.F.; Olson, J.W. and Reno, F.E. (1989): Life time toxicity/carcinogenicity study of FD \& $\mathrm{C}$ red no. 40 (Allura Red) in Sprague Dawley rats. Fd. Chem. Toxic., 27(11):701-706.

Clydesdale, F.M. (1993): Color as a factor in food choice. Critical Reviews in food Science and Nutrition 33:83101.

Doumas, B.T. (1975): Colourimetric determination of total protein in serum or plasma. Clin. Chan., 12:1159-1160.

Fiske, C.H. and Subbarnaw, M. (1925): The colorimetric determination 


\section{Effect of Some Food Colorants}

of phosphorus. J. Biol. Chem. 66:375383.

Ganong, W.E. (1991): Review of medical physiology. 15th ed. Lange Medical Book.

Gaunt, I.F.; Carpanini, F.M.B.; Grasso, P.; Kis, Idas, S. and Gangolli, S.D. (1972): Long term feeding study on brilliant black $\mathrm{PN}$ in rats. $\mathrm{Fd}$ cosmet. Toxicol., 10(1):17-27.

Gaunt, I.F.; Grasso, P.; Kiss, Ida, S. and Gangoll, S.D. (1969): Short term toxicity study on carmoisine in the miniature pig. Food cosmet. Toxicol., 7(1):1-7.

Gaunt, I.F.; Madge Farmer, Grasso, P. and Gangolli, S.D. (1967): Acute (mouse and rat) and short term (rat) toxicity studies on carmoisine. Food cosmet. Toxicol. 5(2), 179-185.

Hallagan, J.B.; Allen, D.C. and Borzelleca, J.F. (1995): The safety and regulatory status of food, drug and cosmetics colour additives exempt from certification $\mathrm{Fd}$ Chem. Toxic. $33 *(6): 515-528$.

Hong, S.P.; Park, H.S.; Lee, M.K. and Hong, C.S. (1989): oral provocation tests with aspirine and food aditives in asthmatic patients. Yonsel Medical J., 30(4):339-345.

Ibrahim, A.Y.; El-Desoky, G.E.; Ramadan, M.E. and Elgendi, S.H. (1988): Comparative studies on the effect of some natural and synthetic food colourants on blood glucose and liver glycogen as well as glutamine aminotransferase in rats. Minia, J. Agric. Res. Rev., 10:1659.

Juhlin, L. (1981): Recurrent urticaria : Clinical investigation of 330 patients. Br. J. Dernatol., 104:369-381.

Mackenzie, K.M.; Boysea, B.G.; Field, W.E.; Petsel, S.R.; Chappel, C.I.; Emerson, J.L. and Stanley, J. (1992): Toxicity of carcinogenicity studies of caramel colour IV in F344 rats and
B6C3F-1 mice. Food and Chemical Toxicology 30(5):431-443.

Newsome, R.L. (1986): Food colours. J. Fd. Technol., 40:49-52.

Osman, M.A.; Afifi, A.; Hussein, R.M.; Kamilia, B.; Abdel Aziz and Salah, S.H. (1995): Long-term biochemical and genotoxicity studies of four synthetic food and drug colorants in mice. Bull. Fac. Pharm. (Cairo Univ.), 33 (1):13-21.

Patton, C. and Crouch, S. (1977): Spectrophotometric and kinetics investigation of the bethelot Reaction for determination of Ammonia. Anal. Chem., 49:464-469.

Ray Sarkar, B.C. and Chauhan, U.P.S. (1967): A new method for determining microquantities of calcium in biological materials. Anal. Biochem., 20:155-166.

Reitman, S. and Frankel, S. (1975): A colorimatric method for the determination of serum glutamic oxaloacetic and glutamic pyravic transaminase. Am. J. Clin. Path. 28:2658.

Robet, K.M.; Darly, K.G.; Peter, A.M. and Victor, W.R. (1993): Harper`s biochemistry large medical publications, 23 rd edition, London, p. 422-435.

Rowe, S.K. (1988): Synthetic food colourings and hyperactivity : a double - blind crossover study. Aust. Paediat. J. 24(2):143-147.

Salah, S.H. (1994): Biochemical studies on some synthetic food colorants. M.Sc. (Blochemistry). Fac. Agric., Cairo Univ.

Schirmeister, O. (1964): Photometric colorimetric, test for kinitic measurements of creatinine. Dtsch, Med. Wschr., 89:1018-1640.

Sharma, S.D. (1989): Renal gross biochemistry of albino rat influenced by a common food color, metanial yellow. 
Journal of advanced Zoology, 10(2):9598.

Sokal, R.R. and Rohlf, F.J. (1981): Biometry : the principles and practica of statistics in biological rresearch. San Francisco 2nd Freeman. W.H. Company.

Straumfjord, J. and Jane, V. (1973): Standardization in bilirubin assays evaluation of selected methods and stability of bilieubia solution. Clin. Chem., 19:984-993.

Twaroj, F.J. (1983): Urticaria in childhood : pathogenesis and management. Pediat. Clin. North. Am., 30:887-898.

Van Bever, H.P.; Doxy, M. and

Stevens, W.J. (1989): Food and food additives in severe atopic dermatitis. Allergy (Copenhagen), 44(8):588-594.

Varley, H. (1976): Practical clinical Biochemistry, Text Book indian Edition, Publishers (India) PVT. Ltd. Sardarjag, Enclave, New Delhi.

Webester, D. (1977): Albumin standards and measurements of serum albumin with bromocresol green. Clin. Chem., 23:663-666.

Table (1): The percentage of mean body weight, hepatosomatic index and kidney /body wt. For young rats treated with different natural and synthetic colorants and their control.

\begin{tabular}{|c|c|c|c|c|c|c|c|c|c|}
\hline & \multicolumn{2}{|c|}{ Periods } & Control & Carmine & Annatto & Tumeric & Sun-set & Chlorophyll & Fast \\
\hline \multirow{2}{*}{$\begin{array}{l}\% \text { of } \\
\text { body } \\
\text { weight } \\
\text { change }\end{array}$} & Treated & $\begin{array}{l}\text { Mean } \\
\pm \text { SE } \\
\text { Significant }\end{array}$ & $\begin{array}{l}35.66 \\
0.80\end{array}$ & $\begin{array}{l}31.86 \\
1.37 \\
<0.05 \\
\end{array}$ & $\begin{array}{l}28.28 \\
0.35 \\
<0.01\end{array}$ & $\begin{array}{l}27.53 \\
1.13 \\
<0.01\end{array}$ & $\begin{array}{l}31.37 \\
0.38 \\
<0.01\end{array}$ & $\begin{array}{l}31.72 \\
1.03 \\
<0.05\end{array}$ & $\begin{array}{l}31.94 \\
0.08 \\
<0.05\end{array}$ \\
\hline & Recovery & $\begin{array}{l}\text { Mean } \\
\pm \text { SE } \\
\text { Significant }\end{array}$ & $\begin{array}{l}38.90 \\
0.82\end{array}$ & $\begin{array}{l}35.02 \\
1.19 \\
<0.05\end{array}$ & $\begin{array}{l}33.27 \\
0.76 \\
<0.01\end{array}$ & $\begin{array}{l}32.94 \\
0.54 \\
<0.01\end{array}$ & $\begin{array}{l}34.16 \\
0.74 \\
<0.01\end{array}$ & $\begin{array}{l}35.30 \\
0.67 \\
<0.05\end{array}$ & $\begin{array}{l}35.82 \\
0.81 \\
<0.05\end{array}$ \\
\hline \multirow{2}{*}{$\begin{array}{l}\text { Hepato- } \\
\text { somatic } \\
\text { index }\end{array}$} & Treated & $\begin{array}{l}\text { Mean } \\
\pm \text { SE } \\
\text { Significant }\end{array}$ & $\begin{array}{l}4.03 \\
0.42\end{array}$ & $\begin{array}{l}3.70 \\
0.48 \\
\text { Insig. }\end{array}$ & $\begin{array}{l}3.30 \\
0.08 \\
\text { Insig. }\end{array}$ & $\begin{array}{l}3.43 \\
0.15 \\
\text { Insig. }\end{array}$ & $\begin{array}{l}3.76 \\
0.05 \\
\text { Insig. }\end{array}$ & $\begin{array}{l}4.84 \\
0.30 \\
\text { Insig. }\end{array}$ & $\begin{array}{l}3.57 \\
0.10 \\
\text { Insig. }\end{array}$ \\
\hline & Recovery & $\begin{array}{l}\text { Mean } \\
\pm \text { SE } \\
\text { Significant }\end{array}$ & $\begin{array}{l}3.74 \\
0.40\end{array}$ & $\begin{array}{l}3.80 \\
0.30 \\
\text { Insig. }\end{array}$ & $\begin{array}{l}3.40 \\
0.15 \\
\text { Insig. }\end{array}$ & $\begin{array}{l}3.50 \\
0.18 \\
\text { Insig. }\end{array}$ & $\begin{array}{l}3.80 \\
0.20 \\
\text { Insig. }\end{array}$ & $\begin{array}{l}4.90 \\
0.70 \\
\text { Insig. }\end{array}$ & $\begin{array}{l}3.45 \\
0.09 \\
\text { Insig. }\end{array}$ \\
\hline \multirow{2}{*}{$\begin{array}{l}\text { Kidney/ } \\
\text { body wt. }\end{array}$} & Treated & $\begin{array}{l}\text { Mean } \\
\pm \text { SE } \\
\text { Significant }\end{array}$ & $\begin{array}{l}0.71 \\
0.01\end{array}$ & $\begin{array}{l}0.86 \\
0.05 \\
\text { Insig. }\end{array}$ & $\begin{array}{l}0.76 \\
0.02 \\
\text { Insig. }\end{array}$ & $\begin{array}{l}0.77 \\
0.03 \\
\text { Insig. }\end{array}$ & $\begin{array}{l}0.78 \\
0.01 \\
\text { Insig. }\end{array}$ & $\begin{array}{l}0.87 \\
0.04 \\
\text { Insig. }\end{array}$ & $\begin{array}{l}0.71 \\
0.01 \\
\text { Insig. }\end{array}$ \\
\hline & Recovery & $\begin{array}{l}\text { Mean } \\
\pm \text { SE } \\
\text { Significant }\end{array}$ & $\begin{array}{l}0.73 \\
0.03\end{array}$ & $\begin{array}{l}0.90 \\
0.04 \\
\text { Insig. }\end{array}$ & $\begin{array}{l}0.80 \\
0.05 \\
\text { Insig. }\end{array}$ & $\begin{array}{l}0.75 \\
0.03 \\
\text { Insig. }\end{array}$ & $\begin{array}{l}0.80 \\
0.04 \\
\text { Insig. }\end{array}$ & $\begin{array}{l}0.90 \\
0.09 \\
\text { Insig. }\end{array}$ & $\begin{array}{l}0.71 \\
0.01 \\
\text { Insig. }\end{array}$ \\
\hline
\end{tabular}


Table (2): The effect of natural and synthetic colorants on AST, ALT, and total, direct and indirect bilirubin in serum of young albino rats

\begin{tabular}{|c|c|c|c|c|c|c|c|c|c|}
\hline $\begin{array}{l}\text { Paramet } \\
\text { ers }\end{array}$ & Periods & & Control & Carmine & Annatto & Tumeric & $\begin{array}{l}\text { Sun-set } \\
\text { yellow }\end{array}$ & Chlorophyll & Fast green \\
\hline \multirow{2}{*}{$\begin{array}{l}\text { AST } \\
\mathrm{u} / \mathrm{L}\end{array}$} & Treated & $\begin{array}{l}\text { Mean } \\
\pm \text { SE } \\
\text { Significant }\end{array}$ & $\begin{array}{l}26.60 \\
0.27\end{array}$ & $\begin{array}{l}31.00 \\
0.40 \\
<0.05 \\
\end{array}$ & $\begin{array}{l}32.00 \\
0.28 \\
<0.05 \\
\end{array}$ & $\begin{array}{l}32.40 \\
0.60 \\
<0.05\end{array}$ & $\begin{array}{l}31.60 \\
0.82 \\
<0.05\end{array}$ & $\begin{array}{l}32.80 \\
0.81 \\
<0.05\end{array}$ & $\begin{array}{l}31.80 \\
0.82 \\
<0.05\end{array}$ \\
\hline & Recovery & $\begin{array}{l}\text { Mean } \\
\pm \text { SE } \\
\text { Significant }\end{array}$ & $\begin{array}{l}26.80 \\
0.22\end{array}$ & $\begin{array}{l}28.00 \\
0.30 \\
\text { Insig. }\end{array}$ & $\begin{array}{l}31.00 \\
0.25 \\
<0.05 \\
\end{array}$ & $\begin{array}{l}30.00 \\
0.50 \\
\text { Insig. }\end{array}$ & $\begin{array}{l}30.60 \\
0.60 \\
<0.05 \\
\end{array}$ & $\begin{array}{l}30.00 \\
0.50 \\
\text { Insig. }\end{array}$ & $\begin{array}{l}29.00 \\
0.40 \\
\text { Insig. }\end{array}$ \\
\hline \multirow{2}{*}{$\begin{array}{l}\text { ALT } \\
\mathrm{u} / \mathrm{L}\end{array}$} & Treated & $\begin{array}{l}\text { Mean } \\
\pm \text { SE } \\
\text { Significant }\end{array}$ & $\begin{array}{l}27.40 \\
0.53\end{array}$ & $\begin{array}{l}30.00 \\
0.40 \\
\text { Insig. }\end{array}$ & $\begin{array}{l}29.80 \\
0.33 \\
\text { Insig. }\end{array}$ & $\begin{array}{l}29.60 \\
0.66 \\
\text { Insig. }\end{array}$ & $\begin{array}{l}31.00 \\
0.40 \\
<0.05\end{array}$ & $\begin{array}{l}30.80 \\
0.33 \\
<0.05\end{array}$ & $\begin{array}{l}30.40 \\
0.21 \\
<0.05\end{array}$ \\
\hline & Recovery & $\begin{array}{l}\text { Mean } \\
\pm \text { SE } \\
\text { Significant }\end{array}$ & $\begin{array}{l}25.90 \\
0.40\end{array}$ & $\begin{array}{l}28.00 \\
0.30 \\
\text { Insig. }\end{array}$ & $\begin{array}{l}29.00 \\
0.30 \\
\text { Insig. }\end{array}$ & $\begin{array}{l}28.00 \\
0.5 \\
\text { Insig. }\end{array}$ & $\begin{array}{l}29.00 \\
0.30 \\
\text { Insig. }\end{array}$ & $\begin{array}{l}30.00 \\
0.30 \\
\text { Insig. }\end{array}$ & $\begin{array}{l}29.00 \\
0.20 \\
\text { Insig. }\end{array}$ \\
\hline \multirow{2}{*}{$\begin{array}{l}\text { Total } \\
\text { bilirubin } \\
\text { mg/dl }\end{array}$} & Treated & $\begin{array}{l}\text { Mean } \\
\pm \text { SE } \\
\text { Significant }\end{array}$ & $\begin{array}{l}0.60 \\
0.06\end{array}$ & $\begin{array}{l}0.75 \\
0.02 \\
<0.05 \\
\end{array}$ & $\begin{array}{l}0.85 \\
0.05 \\
<0.05\end{array}$ & $\begin{array}{l}0.90 \\
0.06 \\
<0.05\end{array}$ & $\begin{array}{l}0.70 \\
0.03 \\
\text { Insig. }\end{array}$ & $\begin{array}{l}0.90 \\
0.04 \\
<0.05\end{array}$ & $\begin{array}{l}0.80 \\
0.03 \\
<0.05\end{array}$ \\
\hline & Recovery & $\begin{array}{l}\text { Mean } \\
\pm \text { SE } \\
\text { Significant }\end{array}$ & $\begin{array}{l}0.60 \\
0.05\end{array}$ & $\begin{array}{l}0.60 \\
0.02 \\
\text { Insig. }\end{array}$ & $\begin{array}{l}0.65 \\
0.04 \\
\text { Insig. }\end{array}$ & $\begin{array}{l}0.70 \\
0.04 \\
\text { Insig. }\end{array}$ & $\begin{array}{l}0.60 \\
0.02 \\
\text { Insig. }\end{array}$ & $\begin{array}{l}0.70 \\
0.04 \\
\text { Insig. }\end{array}$ & $\begin{array}{l}0.7 \\
0.03 \\
\text { Insig. }\end{array}$ \\
\hline \multirow{2}{*}{$\begin{array}{l}\text { Direct } \\
\text { bilirubin } \\
\text { mg/dl }\end{array}$} & Treated & $\begin{array}{l}\text { Mean } \\
\pm \text { SE } \\
\text { Significant }\end{array}$ & $\begin{array}{l}0.21 \\
0.04\end{array}$ & $\begin{array}{l}0.22 \\
0.02 \\
\text { Insig. }\end{array}$ & $\begin{array}{l}0.19 \\
0.06 \\
\text { Insig. }\end{array}$ & $\begin{array}{l}0.19 \\
0.04 \\
\text { Insig. }\end{array}$ & $\begin{array}{l}0.15 \\
0.03 \\
\text { Insig. }\end{array}$ & $\begin{array}{l}0.18 \\
0.05 \\
\text { Insig. }\end{array}$ & $\begin{array}{l}0.16 \\
0.01 \\
\text { Insig. }\end{array}$ \\
\hline & Treated & $\begin{array}{l}\text { Mean } \\
\pm \text { SE } \\
\text { Significant }\end{array}$ & $\begin{array}{l}0.10 \\
0.02\end{array}$ & $\begin{array}{l}0.12 \\
0.01 \\
\text { Insig. }\end{array}$ & $\begin{array}{l}0.14 \\
0.05 \\
\text { Insig. }\end{array}$ & $\begin{array}{l}0.14 \\
0.03 \\
\text { Insig. }\end{array}$ & $\begin{array}{l}0.12 \\
0.04 \\
\text { Insig. }\end{array}$ & $\begin{array}{l}0.12 \\
0.04 \\
\text { Insig. }\end{array}$ & $\begin{array}{l}0.10 \\
0.01 \\
\text { Insig. }\end{array}$ \\
\hline \multirow{2}{*}{$\begin{array}{l}\text { Indirect } \\
\text { bilirubin } \\
\text { mg/dl }\end{array}$} & Recovery & $\begin{array}{l}\text { Mean } \\
\pm \text { SE } \\
\text { Significant }\end{array}$ & $\begin{array}{l}0.40 \\
0.08\end{array}$ & $\begin{array}{l}0.70 \\
0.05 \\
<0.05\end{array}$ & $\begin{array}{l}0.60 \\
0.09 \\
\text { Insig. }\end{array}$ & $\begin{array}{l}0.50 \\
0.05 \\
\text { Insig. }\end{array}$ & $\begin{array}{l}0.70 \\
0.09 \\
<0.05\end{array}$ & $\begin{array}{l}0.70 \\
0.07 \\
<0.05\end{array}$ & $\begin{array}{l}0.60 \\
0.06 \\
\text { Insig. }\end{array}$ \\
\hline & Recovery & $\begin{array}{l}\text { Mean } \\
\pm \text { SE } \\
\text { Significant }\end{array}$ & $\begin{array}{l}0.50 \\
0.12\end{array}$ & $\begin{array}{l}0.75 \\
0.09 \\
\text { Insig. }\end{array}$ & $\begin{array}{l}0.70 \\
0.08 \\
\text { Insig. }\end{array}$ & $\begin{array}{l}0.6 \\
0.12 \\
\text { Insig. }\end{array}$ & $\begin{array}{l}0.70 \\
0.08 \\
\text { Insig. }\end{array}$ & $\begin{array}{l}0.75 \\
0.09 \\
\text { Insig. }\end{array}$ & $\begin{array}{l}0.55 \\
0.01 \\
\text { Insig. }\end{array}$ \\
\hline
\end{tabular}

Table (3): Effect of natural and synthetic colorants on creatinine, urea and uric acid serum of young male rats

\begin{tabular}{|c|c|c|c|c|c|c|c|c|c|}
\hline $\begin{array}{l}\text { Paramet } \\
\text { ers }\end{array}$ & Periods & & Control & Carmine & Annatto & Tumeric & $\begin{array}{l}\text { Sun-set } \\
\text { yellow }\end{array}$ & Chlorophyll & $\begin{array}{l}\text { Fast } \\
\text { green }\end{array}$ \\
\hline \multirow{2}{*}{$\begin{array}{l}\text { Creatinin } \\
\text { e } \mathrm{mg} / \mathrm{dl}\end{array}$} & Treated & $\begin{array}{l}\text { Mean } \\
\pm \text { SE } \\
\text { Significant }\end{array}$ & $\begin{array}{l}0.66 \\
0.05\end{array}$ & $\begin{array}{l}0.84 \\
0.02 \\
<0.05\end{array}$ & $\begin{array}{l}1.12 \\
0.04 \\
<0.01\end{array}$ & $\begin{array}{l}0.78 \\
0.05 \\
\text { Insig. }\end{array}$ & $\begin{array}{l}0.70 \\
0.04 \\
\text { Insig. }\end{array}$ & $\begin{array}{l}0.86 \\
0.08 \\
<0.05\end{array}$ & $\begin{array}{l}0.96 \\
0.12 \\
<0.05\end{array}$ \\
\hline & Recovery & $\begin{array}{l}\text { Mean } \\
\pm \text { SE } \\
\text { Significant }\end{array}$ & $\begin{array}{l}0.76 \\
0.04\end{array}$ & $\begin{array}{l}0.80 \\
0.01 \\
\text { Insig. }\end{array}$ & $\begin{array}{l}0.90 \\
0.02 \\
<0.05\end{array}$ & $\begin{array}{l}0.70 \\
0.04 \\
\text { Insig. }\end{array}$ & $\begin{array}{l}0.70 \\
0.03 \\
\text { Insig. }\end{array}$ & $\begin{array}{l}0.80 \\
0.05 \\
\text { Insig. }\end{array}$ & $\begin{array}{l}0.90 \\
0.08 \\
<0.05\end{array}$ \\
\hline \multirow{2}{*}{$\begin{array}{l}\text { Urea } \\
\mathrm{mg} / \mathrm{dl}\end{array}$} & Treated & $\begin{array}{l}\text { Mean } \\
\pm \text { SE } \\
\text { Significant }\end{array}$ & $\begin{array}{l}21.60 \\
1.28\end{array}$ & $\begin{array}{l}27.40 \\
0.77 \\
<0.01\end{array}$ & $\begin{array}{l}26.80 \\
0.71 \\
<0.01\end{array}$ & $\begin{array}{l}28.60 \\
0.87 \\
<0.01\end{array}$ & $\begin{array}{l}28.60 \\
0.76 \\
<0.01\end{array}$ & $\begin{array}{l}28.20 \\
0.42 \\
<0.01\end{array}$ & $\begin{array}{l}26.00 \\
0.40 \\
<0.01\end{array}$ \\
\hline & Recovery & $\begin{array}{l}\text { Mean } \\
\pm \text { SE } \\
\text { Significant }\end{array}$ & $\begin{array}{l}20.80 \\
0.70\end{array}$ & $\begin{array}{l}23.40 \\
0.65 \\
<0.05\end{array}$ & $\begin{array}{l}23.00 \\
0.51 \\
<0.05\end{array}$ & $\begin{array}{l}24.50 \\
0.52 \\
<0.05\end{array}$ & $\begin{array}{l}23.00 \\
0.45 \\
<0.05\end{array}$ & $\begin{array}{l}23.00 \\
0.31 \\
<0.05\end{array}$ & $\begin{array}{l}24.00 \\
0.45 \\
<0.05\end{array}$ \\
\hline \multirow{2}{*}{$\begin{array}{l}\text { Uric acid } \\
\mathrm{mg} / \mathrm{dl}\end{array}$} & Treated & $\begin{array}{l}\text { Mean } \\
\pm \text { SE } \\
\text { Significant }\end{array}$ & $\begin{array}{l}4.44 \\
0.25\end{array}$ & $\begin{array}{l}4.90 \\
0.29 \\
\text { Insig. }\end{array}$ & $\begin{array}{l}5.00 \\
0.28 \\
\text { Insig. }\end{array}$ & $\begin{array}{l}5.20 \\
0.33 \\
\text { Insig. }\end{array}$ & $\begin{array}{l}4.94 \\
0.23 \\
\text { Insig. }\end{array}$ & $\begin{array}{l}4.66 \\
0.16 \\
\text { Insig. }\end{array}$ & $\begin{array}{l}4.90 \\
0.13 \\
\text { Insig. }\end{array}$ \\
\hline & Recovery & $\begin{array}{l}\text { Mean } \\
\pm \text { SE } \\
\text { Significant }\end{array}$ & $\begin{array}{l}4.40 \\
0.20\end{array}$ & $\begin{array}{l}4.70 \\
0.25 \\
\text { Insig. }\end{array}$ & $\begin{array}{l}4.90 \\
0.30 \\
\text { Insig. }\end{array}$ & $\begin{array}{l}5.00 \\
0.27 \\
\text { Insig. }\end{array}$ & $\begin{array}{l}4.80 \\
0.16 \\
\text { Insig. }\end{array}$ & $\begin{array}{l}4.50 \\
0.17 \\
\text { Insig. }\end{array}$ & $\begin{array}{l}4.75 \\
0.23 \\
\text { Insig. }\end{array}$ \\
\hline
\end{tabular}


Table (4): Effect of natural and synthetic colorants on serum protein, albumin and globulin in young male rats

\begin{tabular}{|c|c|c|c|c|c|c|c|c|c|}
\hline $\begin{array}{l}\text { Paramet } \\
\text { ers }\end{array}$ & Periods & & Control & Carmine & Annatto & Tumeric & $\begin{array}{l}\text { Sun-set } \\
\text { yellow }\end{array}$ & Chlorophyll & $\begin{array}{l}\text { Fast } \\
\text { green }\end{array}$ \\
\hline \multirow{2}{*}{$\begin{array}{l}\text { Serum } \\
\text { total } \\
\text { protein } \\
\mathrm{g} / \mathrm{dl}\end{array}$} & Treated & $\begin{array}{l}\text { Mean } \\
\pm \text { SE } \\
\text { Significant }\end{array}$ & $\begin{array}{l}6.00 \\
0.34\end{array}$ & $\begin{array}{l}5.10 \\
0.30 \\
<0.05 \\
\end{array}$ & $\begin{array}{l}5.20 \\
0.12 \\
\text { Insig. }\end{array}$ & $\begin{array}{l}5.84 \\
0.16 \\
\text { Insig. }\end{array}$ & $\begin{array}{l}5.14 \\
0.12 \\
<0.05 \\
\end{array}$ & $\begin{array}{l}5.34 \\
0.11 \\
\text { Insig. }\end{array}$ & $\begin{array}{l}5.32 \\
0.09 \\
\text { Insig. }\end{array}$ \\
\hline & Recovery & $\begin{array}{l}\text { Mean } \\
\pm \text { SE } \\
\text { Significant }\end{array}$ & $\begin{array}{l}5.60 \\
0.30\end{array}$ & $\begin{array}{l}6.00 \\
0.45 \\
\text { Insig. }\end{array}$ & $\begin{array}{l}6.00 \\
0.25 \\
\text { Insig. }\end{array}$ & $\begin{array}{l}5.80 \\
0.30 \\
\text { Insig. }\end{array}$ & $\begin{array}{l}6.20 \\
0.20 \\
\text { Insig. }\end{array}$ & $\begin{array}{l}5.80 \\
0.20 \\
\text { Insig. }\end{array}$ & $\begin{array}{l}5.60 \\
0.15 \\
\text { Insig. }\end{array}$ \\
\hline \multirow{2}{*}{$\begin{array}{l}\text { Serum } \\
\text { albumin } \\
\text { g/dl }\end{array}$} & Treated & $\begin{array}{l}\text { Mean } \\
\pm \text { SE } \\
\text { Significant }\end{array}$ & $\begin{array}{l}3.46 \\
0.14\end{array}$ & $\begin{array}{l}3.16 \\
0.06 \\
\text { Insig. }\end{array}$ & $\begin{array}{l}3.18 \\
0.05 \\
\text { Insig. }\end{array}$ & $\begin{array}{l}3.12 \\
0.05 \\
\text { Insig. }\end{array}$ & $\begin{array}{l}3.18 \\
0.11 \\
\text { Insig. }\end{array}$ & $\begin{array}{l}3.14 \\
0.15 \\
\text { Insig. }\end{array}$ & $\begin{array}{l}3.30 \\
0.09 \\
\text { Insig. }\end{array}$ \\
\hline & Recovery & $\begin{array}{l}\text { Mean } \\
\pm \text { SE } \\
\text { Significant }\end{array}$ & $\begin{array}{l}4.20 \\
0.15\end{array}$ & $\begin{array}{l}3.90 \\
0.04 \\
\text { Insig. }\end{array}$ & $\begin{array}{l}3.80 \\
0.14 \\
\text { Insig. }\end{array}$ & $\begin{array}{l}3.70 \\
0.15 \\
\text { Insig. }\end{array}$ & $\begin{array}{l}3.90 \\
0.15 \\
\text { Insig. }\end{array}$ & $\begin{array}{l}3.60 \\
0.19 \\
\text { Insig. }\end{array}$ & $\begin{array}{l}3.60 \\
0.18 \\
\text { Insig. }\end{array}$ \\
\hline \multirow{2}{*}{$\begin{array}{l}\text { Serum } \\
\text { globulin } \\
\text { g/dl }\end{array}$} & Treated & $\begin{array}{l}\text { Mean } \\
\pm \text { SE } \\
\text { Significant }\end{array}$ & $\begin{array}{l}2.74 \\
0.13\end{array}$ & $\begin{array}{l}1.94 \\
0.20 \\
<0.01\end{array}$ & $\begin{array}{l}2.90 \\
0.12 \\
\text { Insig. }\end{array}$ & $\begin{array}{l}2.72 \\
0.17 \\
\text { Insig. }\end{array}$ & $\begin{array}{l}1.84 \\
0.11 \\
<0.01\end{array}$ & $\begin{array}{l}2.20 \\
0.20 \\
<0.05\end{array}$ & $\begin{array}{l}2.16 \\
0.20 \\
< \\
0.05\end{array}$ \\
\hline & Recovery & $\begin{array}{l}\text { Mean } \\
\pm \text { SE } \\
\text { Significant }\end{array}$ & $\begin{array}{l}2.30 \\
0.10\end{array}$ & $\begin{array}{l}2.10 \\
0.10 \\
\text { Insig. }\end{array}$ & $\begin{array}{l}2.20 \\
0.10 \\
\text { Insig. }\end{array}$ & $\begin{array}{l}2.20 \\
0.10 \\
\text { Insig. }\end{array}$ & $\begin{array}{l}2.30 \\
0.09 \\
\text { Insig. }\end{array}$ & $\begin{array}{l}2.20 \\
0.10 \\
\text { Insig. }\end{array}$ & $\begin{array}{l}2.00 \\
0.15 \\
\text { Insig. }\end{array}$ \\
\hline
\end{tabular}

Table (5): The effect of natural and synthetic colorants on total protein of liver,

kidney, heart, muscle and brain of young albino rats

\begin{tabular}{|c|c|c|c|c|c|c|c|c|c|}
\hline Parameters & Periods & & Control & Carmine & Annatto & Tumeric & $\begin{array}{l}\text { Sun-set } \\
\text { yellow }\end{array}$ & Chlorophyll & $\begin{array}{l}\text { Fast } \\
\text { green }\end{array}$ \\
\hline \multirow{2}{*}{$\begin{array}{l}\text { Liver protein } \\
\mathrm{mg} / \mathrm{g} \text { tissue }\end{array}$} & Treated & $\begin{array}{l}\text { Mean } \\
\pm \text { SE } \\
\text { Significant }\end{array}$ & $\begin{array}{l}31.28 \\
0.15\end{array}$ & $\begin{array}{l}31.28 \\
0.09 \\
\text { Insig. }\end{array}$ & $\begin{array}{l}31.40 \\
0.15 \\
\text { Insig. }\end{array}$ & $\begin{array}{l}31.32 \\
0.20 \\
\text { Insig. }\end{array}$ & $\begin{array}{l}31.26 \\
0.06 \\
\text { Insig. }\end{array}$ & $\begin{array}{l}31.34 \\
0.11 \\
\text { Insig. }\end{array}$ & $\begin{array}{l}31.24 \\
0.14 \\
\text { Insig. }\end{array}$ \\
\hline & Recovery & $\begin{array}{l}\text { Mean } \\
\pm \text { SE } \\
\text { Significant }\end{array}$ & $\begin{array}{l}31.75 \\
0.05\end{array}$ & $\begin{array}{l}31.20 \\
0.12 \\
\text { Insig. }\end{array}$ & $\begin{array}{l}31.87 \\
0.01 \\
\text { Insig. }\end{array}$ & $\begin{array}{l}31.88 \\
0.23 \\
\text { Insig. }\end{array}$ & $\begin{array}{l}31.00 \\
0.15 \\
\text { Insig. }\end{array}$ & $\begin{array}{l}31.00 \\
0.15 \\
\text { Insig. }\end{array}$ & $\begin{array}{l}31.93 \\
0.10 \\
\text { Insig. }\end{array}$ \\
\hline \multirow{2}{*}{$\begin{array}{l}\text { Kidney } \\
\text { protein mg/g } \\
\text { tissue }\end{array}$} & Treated & $\begin{array}{l}\text { Mean } \\
\pm \text { SE } \\
\text { Significant }\end{array}$ & $\begin{array}{l}14.57 \\
0.05\end{array}$ & $\begin{array}{l}14.02 \\
0.17 \\
\text { Insig. }\end{array}$ & $\begin{array}{l}14.34 \\
0.12 \\
\text { Insig. }\end{array}$ & $\begin{array}{l}14.38 \\
0.21 \\
\text { Insig. }\end{array}$ & $\begin{array}{l}14.16 \\
0.06 \\
\text { Insig. }\end{array}$ & $\begin{array}{l}14.02 \\
0.13 \\
\text { Insig. }\end{array}$ & $\begin{array}{l}14.38 \\
0.19 \\
\text { Insig. }\end{array}$ \\
\hline & Recovery & $\begin{array}{l}\text { Mean } \\
\pm \text { SE } \\
\text { Significant }\end{array}$ & $\begin{array}{l}14.36 \\
0.19\end{array}$ & $\begin{array}{l}13.78 \\
0.15 \\
\text { Insig. }\end{array}$ & $\begin{array}{l}13.49 \\
0.13 \\
\text { Insig. }\end{array}$ & $\begin{array}{l}13.51 \\
0.15 \\
\text { Insig. }\end{array}$ & $\begin{array}{l}14.16 \\
0.12 \\
\text { Insig. }\end{array}$ & $\begin{array}{l}13.50 \\
0.12 \\
\text { Insig. }\end{array}$ & $\begin{array}{l}13.95 \\
0.16 \\
\text { Insig. }\end{array}$ \\
\hline \multirow{2}{*}{$\begin{array}{l}\text { Heart } \\
\text { protein } \mathrm{mg} / \mathrm{g} \\
\text { tissue }\end{array}$} & Treated & $\begin{array}{l}\text { Mean } \\
\pm \text { SE } \\
\text { Significant }\end{array}$ & $\begin{array}{l}84.42 \\
0.12\end{array}$ & $\begin{array}{l}83.90 \\
0.19 \\
\text { Insig. }\end{array}$ & $\begin{array}{l}83.98 \\
0.18 \\
\text { Insig. }\end{array}$ & $\begin{array}{l}84.30 \\
0.15 \\
\text { Insig. }\end{array}$ & $\begin{array}{l}83.95 \\
0.16 \\
\text { Insig. }\end{array}$ & $\begin{array}{l}84.60 \\
0.10 \\
\text { Insig. }\end{array}$ & $\begin{array}{l}83.94 \\
0.11 \\
\text { Insig. }\end{array}$ \\
\hline & Recovery & $\begin{array}{l}\text { Mean } \\
\pm \text { SE } \\
\text { Significant }\end{array}$ & $\begin{array}{l}83.95 \\
0.13\end{array}$ & $\begin{array}{l}84.00 \\
0.16 \\
\text { Insig. }\end{array}$ & $\begin{array}{l}83.88 \\
0.21 \\
\text { Insig. }\end{array}$ & $\begin{array}{l}83.60 \\
0.19 \\
\text { Insig. }\end{array}$ & $\begin{array}{l}83.86 \\
0.19 \\
\text { Insig. }\end{array}$ & $\begin{array}{l}84.28 \\
0.23 \\
\text { Insig. }\end{array}$ & $\begin{array}{l}83.53 \\
0.14 \\
\text { Insig. }\end{array}$ \\
\hline \multirow{2}{*}{$\begin{array}{l}\text { Muscle } \\
\text { protein } \mathrm{mg} / \mathrm{g} \\
\text { tissue }\end{array}$} & Treated & $\begin{array}{l}\text { Mean } \\
\pm \text { SE } \\
\text { Significant }\end{array}$ & $\begin{array}{l}114.16 \\
0.20\end{array}$ & $\begin{array}{l}114.06 \\
0.08 \\
\text { Insig. }\end{array}$ & $\begin{array}{l}114.30 \\
0.12 \\
\text { Insig. }\end{array}$ & $\begin{array}{l}114.14 \\
0.21 \\
\text { Insig. }\end{array}$ & $\begin{array}{l}114.62 \\
0.15 \\
\text { Insig. }\end{array}$ & $\begin{array}{l}113.92 \\
0.15 \\
\text { Insig. }\end{array}$ & $\begin{array}{l}114.26 \\
0.17 \\
\text { Insig. }\end{array}$ \\
\hline & Treated & $\begin{array}{l}\text { Mean } \\
\pm \text { SE } \\
\text { Significant }\end{array}$ & $\begin{array}{l}114.11 \\
0.16\end{array}$ & $\begin{array}{l}114.14 \\
0.13 \\
\text { Insig. }\end{array}$ & $\begin{array}{l}113.77 \\
0.06 \\
\text { Insig. }\end{array}$ & $\begin{array}{l}113.88 \\
0.23 \\
\text { Insig. }\end{array}$ & $\begin{array}{l}113.70 \\
0.14 \\
\text { Insig. }\end{array}$ & $\begin{array}{l}114.06 \\
0.15 \\
\text { Insig. }\end{array}$ & $\begin{array}{l}113.93 \\
0.09 \\
\text { Insig. }\end{array}$ \\
\hline \multirow{2}{*}{$\begin{array}{l}\text { Brain protein } \\
\mathrm{mg} / \mathrm{g} \text { tissue }\end{array}$} & Treated & $\begin{array}{l}\text { Mean } \\
\pm \text { SE } \\
\text { Significant }\end{array}$ & $\begin{array}{l}115.92 \\
0.17\end{array}$ & $\begin{array}{l}115.82 \\
0.13 \\
\text { Insig. }\end{array}$ & $\begin{array}{l}115.2 \\
0.09 \\
\text { Insig. }\end{array}$ & $\begin{array}{l}115.18 \\
0.07 \\
\text { Insig. }\end{array}$ & $\begin{array}{l}115.84 \\
0.13 \\
\text { Insig. }\end{array}$ & $\begin{array}{l}115.86 \\
0.13 \\
\text { Insig. }\end{array}$ & $\begin{array}{l}115.95 \\
0.15 \\
\text { Insig. }\end{array}$ \\
\hline & Recovery & $\begin{array}{l}\text { Mean } \\
\pm \text { SE } \\
\text { Significant }\end{array}$ & $\begin{array}{l}115.52 \\
0.14\end{array}$ & $\begin{array}{l}115.90 \\
0.10 \\
\text { Insig. }\end{array}$ & $\begin{array}{l}115.73 \\
0.06 \\
\text { Insig. }\end{array}$ & $\begin{array}{l}115.58 \\
0.06 \\
\text { Insig. }\end{array}$ & $\begin{array}{l}115.20 \\
0.12 \\
\text { Insig. }\end{array}$ & $\begin{array}{l}115.92 \\
0.10 \\
\text { Insig. }\end{array}$ & $\begin{array}{l}115.52 \\
0.07 \\
\text { Insig. }\end{array}$ \\
\hline
\end{tabular}


Table (6): The effect of natural and synthetic colorants on phosphorus and calcium in serum young albino rats.

\begin{tabular}{|c|c|c|c|c|c|c|c|c|c|}
\hline $\begin{array}{l}\text { Paramet } \\
\text { ers }\end{array}$ & \multicolumn{2}{|l|}{ Periods } & \multirow{2}{*}{$\begin{array}{l}\text { Control } \\
13.14 \\
1.01\end{array}$} & \multirow{2}{*}{$\begin{array}{l}\text { Carmine } \\
\\
15.66 \\
1.02 \\
\text { Insia }\end{array}$} & \multirow{2}{*}{$\begin{array}{l}\text { Annatto } \\
\\
16.00 \\
0.73 \\
\text { Insig. }\end{array}$} & \multirow{2}{*}{$\begin{array}{l}\text { Tumeric } \\
\\
15.60 \\
1.01 \\
\text { Insig. }\end{array}$} & \multirow{2}{*}{$\begin{array}{l}\begin{array}{l}\text { Sun-set } \\
\text { yellow }\end{array} \\
15.20 \\
0.74 \\
\text { Insig. }\end{array}$} & \multirow{2}{*}{$\begin{array}{l}\text { Chlorophyll } \\
\\
15.22 \\
0.70 \\
\text { Insig. }\end{array}$} & \multirow{2}{*}{$\begin{array}{l}\begin{array}{l}\text { Fast } \\
\text { green }\end{array} \\
15.54 \\
0.72 \\
\text { Insig }\end{array}$} \\
\hline Serum & Treated & $\begin{array}{l}\text { Mean } \\
\pm \text { SE } \\
\text { Significant }\end{array}$ & & & & & & & \\
\hline $\begin{array}{l}\text { phosphor } \\
\text { us mg/dl }\end{array}$ & Recovery & $\begin{array}{l}\text { Mean } \\
\pm \text { SE } \\
\text { Significant }\end{array}$ & $\begin{array}{l}13.40 \\
0.24\end{array}$ & $\begin{array}{l}13.90 \\
0.44 \\
\text { Insig. }\end{array}$ & $\begin{array}{l}14.30 \\
0.37 \\
\text { Insig. }\end{array}$ & $\begin{array}{l}14.00 \\
0.31 \\
\text { Insig. }\end{array}$ & $\begin{array}{l}13.90 \\
0.28 \\
\text { Insig. }\end{array}$ & $\begin{array}{l}14.10 \\
0.31 \\
\text { Insig. }\end{array}$ & $\begin{array}{l}14.10 \\
0.55 \\
\text { Insig. }\end{array}$ \\
\hline \multirow{2}{*}{$\begin{array}{l}\text { Serum } \\
\text { calcium } \\
\mathrm{mg} / \mathrm{dl}\end{array}$} & Treated & $\begin{array}{l}\text { Mean } \\
\pm \text { SE } \\
\text { Significant }\end{array}$ & $\begin{array}{l}10.70 \\
0.99\end{array}$ & $\begin{array}{l}8.20 \\
0.74 \\
\text { Insig. }\end{array}$ & $\begin{array}{l}7.90 \\
1.00 \\
\text { Insig. }\end{array}$ & $\begin{array}{l}8.48 \\
1.12 \\
\text { Insig. }\end{array}$ & $\begin{array}{l}8.10 \\
0.80 \\
\text { Insig. }\end{array}$ & $\begin{array}{l}8.02 \\
0.97 \\
\text { Insig. }\end{array}$ & $\begin{array}{l}8.30 \\
0.74 \\
\text { Insig. }\end{array}$ \\
\hline & Recovery & $\begin{array}{l}\text { Mean } \\
\pm \text { SE } \\
\text { Significant }\end{array}$ & $\begin{array}{l}10.00 \\
0.30\end{array}$ & $\begin{array}{l}9.50 \\
0.30 \\
\text { Insig. }\end{array}$ & $\begin{array}{l}9.10 \\
0.40 \\
\text { Insig. }\end{array}$ & $\begin{array}{l}9.50 \\
0.45 \\
\text { Insig. }\end{array}$ & $\begin{array}{l}9.50 \\
0.30 \\
\text { Insig. }\end{array}$ & $\begin{array}{l}9.50 \\
0.20 \\
\text { Insig. }\end{array}$ & $\begin{array}{l}9.60 \\
0.30 \\
\text { Insig. }\end{array}$ \\
\hline
\end{tabular}

تأثير بعض ملونات الغذاء (المخلقة و الطبيعية)علي الجرذان البيضاء

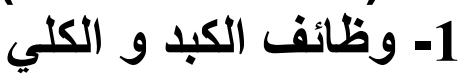

\section{1- ايمان جمال الدين هلال ، 2- سمير عطية زعقوق 3- تمدي مكاوي}

1- قسم علم الحيوان ـ كلية العلوم ـ جامعة الأزهر ـ فرع البنات ـ مدينة نصر ـ القاهرة

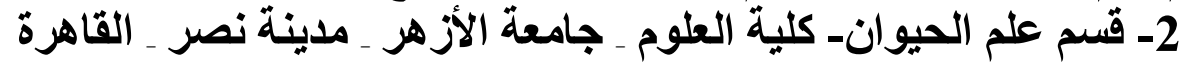

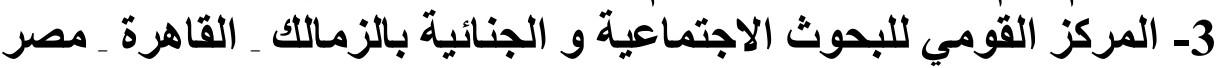

تستخدم ملونات الغذاء في أنحاء العالم بكميات كبيرة إلا أن استخدامها في الغذاء محل جدال . و و

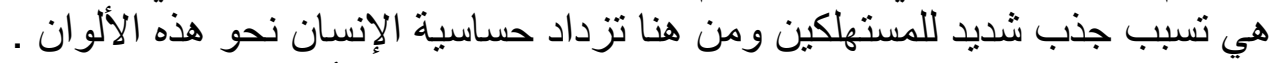

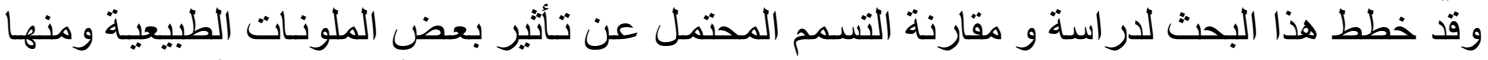

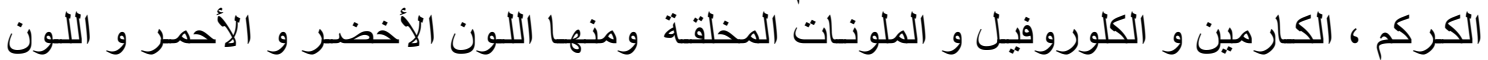

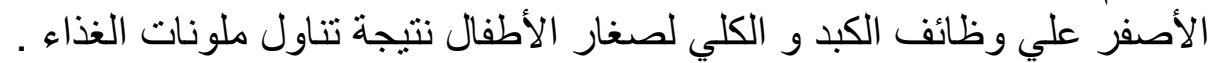

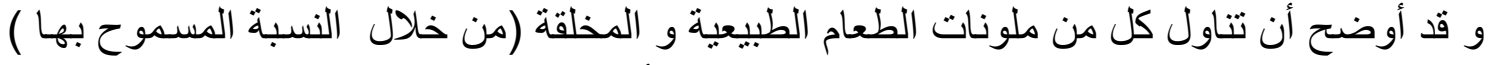

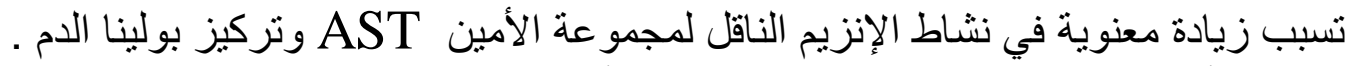

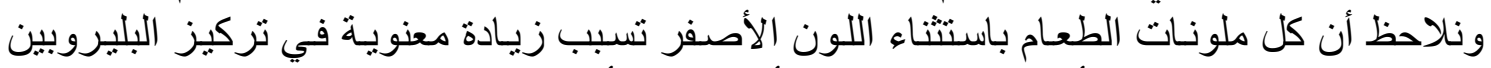

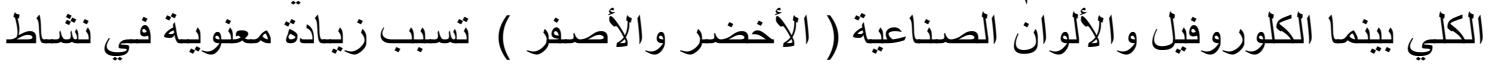

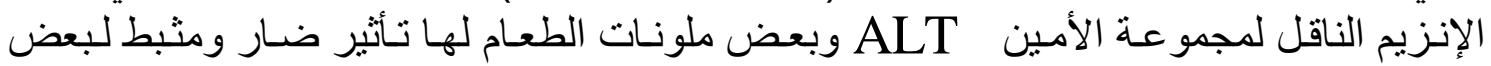

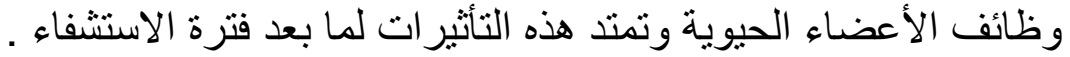

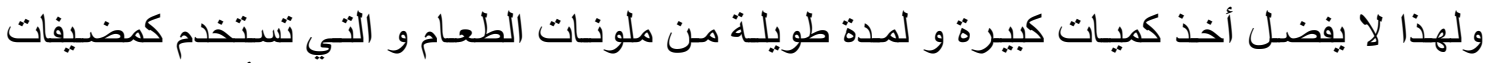

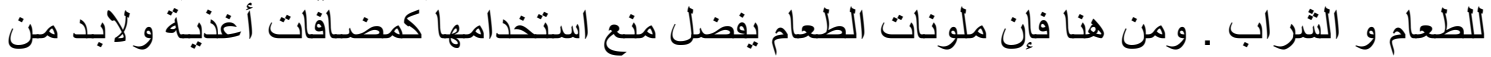
عناية كاملة لإبعاد الأطفال من أكل أو شرب هذب هذه الملونات بكميات كبيرة و لمدة طويلة . 